PEOPLE: International Journal of Social Sciences

ISSN 2454-5899

Ruth Frimpomaa Anarfi Gordon, 2021

Volume 7 Issue 3, pp. 42-58

Received: 29th April 2021

Revised: 28th July 2021, $7^{\text {th }}$ August 2021, 18 th October 2021

Accepted: $1^{\text {st }}$ December 2021

Date of Publication: 15th December 2021

DOI- https://doi.org/10.20319/pijss.2021.73.4258

This paper can be cited as: Gordon, R. F. A. (2021). The Interrelationship Between Rape and Constructions of Masculinity and Development Assistance in the Democratic Republic of Congo (DRC). PEOPLE: International Journal of Social Sciences, 7(3), 42-58.

This work is licensed under the Creative Commons Attribution-Non-Commercial 4.0 International License. To view a copy of this license, visit http://creativecommons.org/licenses/by-nc/4.0/ or send a letter to Creative Commons, PO Box 1866, Mountain View, CA 94042, USA.

\title{
THE INTERRELATIONSHIP BETWEEN RAPE AND CONSTRUCTIONS OF MASCULINITY AND DEVELOPMENT ASSISTANCE IN THE DEMOCRATIC REPUBLIC OF CONGO (DRC)
}

\author{
Ruth Frimpomaa Anarfi Gordon \\ Faculty of Academic Affairs and Research (FAAR), Department of Peace and Security, Kofi \\ Annan International Peacekeeping Training Center, Accra, Ghana \\ frimpomaagordon84@gmail.com \\ frimpomaaafia@yahoo.com
}

\begin{abstract}
War is an event, at its occurrence destroys nations. More than five million lives were claimed during the conflict of the DRC. It caused heinous destruction to properties, infrastructure, impeded national growth, and caused a lot of citizens, especially women and girls to suffer greatly, in addition, stereotyping the nation as "the rape capital of the world". It is against this background that this study sought to delve into the case of the DRC to explore why the DRC was tagged "the capital of rape in the world". To find out why rape was used as a weapon of war against women and girls. To explore whether it was a way of money-making by the influence of external bodies or a belief. This study employed a qualitative approach relying on administered questionnaires, literature from publications, presented papers, journals, books, and useful websites. Pert the findings or results, rape cases in the DRC is not a belief, but rare cases and in a way, money-making on the part of some NGOs and indigenes. This paper concludes with some questions: Are neighbouring countries and international organizations still trooping in to exploit the natural resources of DRC? Is the DRC truly the "rape
\end{abstract}


capital of the world"? Is this not a myth or probably a stereotype since some NGOs offer natives the platform to inflate the figures based on forging rape to get medical attention? This is a wake-up call for the African Union, the United Nations, Human Rights Watch etc. to take strict measures to curb the menace (violence against women and girls during conflicts or wars).

\section{Keywords}

War, Feminism, Sexual Violence, The Rape Capital, The DRC

\section{Introduction}

During armed conflict, soldiers consistently capture women and coerce them to play the role of wives, basically compelling them to cook, clean, wash clothes, and harass them sexually, all of which are seen as gender-specific forms of labour (Baaz, 2009). Such acts, of course, reduce relationships during peacekeeping, and mostly on occasions where free labour and marriages are a common practice. This exposes women to all forms of social stereotype perception during the war and exposes them to high risks for abduction and abuse (Harris et al, 2015).

Rape throughout history is generally perceived as an expected waring act that breeds vengeance triumph for the winning party. The DRC conflict which started in 1996 ended Mobutu Sese Seko's 31-year ruling and left the country in turmoil. This conflict primarily included nine African countries, numerous UN peacekeeping groups and twenty armed groups (Duncan, 2004). This resulted in 5.4 million deaths. The DRC is well endowed with natural resources, however, political unrest, a culture of corruption and lack of infrastructure have hindered national growth (Simon et al., 2006).

The rate of sexual abuse caused by both government forces and rebel groups attracted attention from both international policymakers and advocacy groups to intervene. Further, irrespective of measures taken by international bodies to curb this menace, sexual abuse increased at the hands of armed men. This research described the conflict of the DRC and highlighted the reasons for rape during the crisis. It also argued various reasons that prompted soldiers to rape during the conflict and believe that those reasons are connected to several masculinities. Also, the studies discussed the concern about Eastern DR Congo being labelled as the capital of rape universally (Brown, 2011).

\subsection{Why the DRC, is "the Capital of Rape"?}

In major rape cases, as shown by studies, the use of coercion by the culprits resulted in physical injuries coupled with threats of death and intimidation is enough to destroy one's life (Green 1987; Weekly 1986) (Easteal 2011). Many secrets' forces may be meted on a rape victim, but it is up to the victim to decide to complain or not. On the other hand, most sexually abused persons might 
decide to keep mute about their situations since their existence might be a result of incest, and as humans, they will cope with the situation to survive (Lundberg-love, 1999). Others may also decide to socialize and refuse to seek help due to lack of support and failure of physical and emotional strength to face the ridicules that are associated with rape, hence apathy in females is a common response to violence from men. Sadly, some groups of the criminal justice system still accept this as a tale, that the sexually abused who is without facts of injuries by way of resisting is a storyteller regardless of the real variance in reality. Mostly rape victims are not to be held accountable for their assaults, rape assaults in the DRC were used as a weapon of war to satisfy egotistical desires.

Sexually abused women and girls in the DRC war were reported to be 1.8 million (Tear fund's HIV\& SV Unit report, 2014). In 1991, abuses were recognized but became prevalent in 1994 in the numerous provinces of the DRC, (Pratt, \& Werchick, 2004). As of 2004, USAID/DCHA Assessment reported the outcome of sexual assault reached beyond and leaders of communities recognized the persistent crime meted on the indigenes with such inconsideration. Using rape as a weapon of war in waring states seem to be too calculated, spreads so fast and is too potent for it not to be part of a political scheme. The masses contended that this search/phenomenon must have a clear gendered understanding of violence during wars, (the International Peace Research Institute, 2001). This implies that trying to investigate sexual abuse without constantly reading how the path of war is, likewise an execution of the relations of the male and female is unexecuted.

Reasons for which people sexually abuse women and girls vary from person to person. Most people, in the case of DRC, describes some ways rebels and some Congolese army used rape as a weapon of war to get back at their opponents (Wolf et al, 2014). That is "to terrify or coerce them, oftentimes it is used to fetch information about separatists (rebels), to control resources or territories. Again, to fortify themselves to prevent death in the course of waring or for ethnic cleansing (that is to be protected by way of abiding by the conditions of the magic potion to make their fortification work to defeat their enemy). Also, to humiliate, to express frustration or anger, to control communities, territory or resources. To add, to terminate pregnancies, to increase food insecurity, to retaliate, to avoid violence from superiors, to silence etc." Rebels in waring states have the notion that rape is a fantastic, effective and economical weapon that is more destructive than guns, bullets and bombs and that girls and women become the targeted group because they are part of a community, religious body, ethnic or the nation (Amnesty International, 2007).

\subsection{The Effects of Wars and Sexual Violence on Girls and Women}

Violence against women during or after armed conflicts has been reported in every international or non-international organization and rape as a weapon of war is designed to humiliate. It also has serious short-and long-term effects on victims which may result in a high mortality rate, 
causing the extermination of many citizens, especially women and vulnerable children (Pratt \& Werchick, 2004). Regarding Wax (2003), sexual abuse and violence destroy one's spirit, soul and body, and recovering from it is very complex and cannot be assured, because the internal damages may be complicated as victims may experience tearing in the reproductive system which may result in fistulas, complications in childbirth, menstrual disorders, anal disorders and all of these affect the growth of population.

As complicated as this might be, it also has socio-economic implications impeding the movements and workforce cooperation and attendance of schools of women and girls as well. However, a rape survivor can face lifelong ostracism from his/her community, can be stereotyped for being labelled rape victim, the rebel's wife or even the enemy's child. The economic and social dependence of women on men in many societies contributes to their fear of reporting rape cases. The indication of this is that the labour force could be at risk, people, most importantly, women and the youth who could work will no longer think of working, hence reduction in labour. As (Cammaert, 2008), said, "It is now more dangerous to be a woman than to be a soldier in a modern conflict because where war exists rape will surely occur". Aside from all these effects, rape according to (Penn \& Nardos, 2003:57) (Pratt \& Wechick, 2004) spreads diseases such as STIs (Sexually Transmitted Infections) and HIVs etc. which could compel governments of such countries to spend hugely on the state's health facilities.

\section{Method and Materials (Research Design)}

The research used a random sampling technique to collect data using the issue of rape in DR. Congo and the role in dealing with atrocities committed against women and young girls during the two wars. This approach aimed to make an accurate choice based on understanding exactly who to add to the sample. This was a case study on the people of North Kivu and based on the fieldwork undertaken. Aside from the primary data, the research utilized three search engines -scholarly resources of open access directory, google scholar, and research gate to support the secondary data.

\subsection{Study Population, Sampling Procedure and Rationale}

The targeted population was the affected women and young girls of North Kivu.

The research employed the qualitative approach and interview approach using questionnaires as the primary source of data needed for the study. The research sought to use these sources of data collection to enable the researcher to weigh the issues emerging from the sources to arrive at a quality result. 


\subsubsection{Sampling Size and Justification}

Considering the population of Goma, a random sample population of sixty was considered for the research. Sixty respondents formed part of the population that was understudied to gather the needed data for the research and the respondents were sampled randomly.

\subsection{Data Collection Technique}

The main instrument to collect data from respondents was a structured and unstructured interview questionnaire which consisted of approximately 53 questions. Respondents were asked to tick the appropriate box corresponding to the answer. The study used both closed and open-ended questions to cater for their individual preferences.

\section{Background Information and Results}

This section presents and discusses the findings collected. The results were categorized into three parts. The first part deals with the background information of the respondents by looking at their age, educational background, marital status, and religion. The second section presents analysis and discussions of answers provided by those interviewed in both structured and unstructured formats. The respondent's data are reported in both tabular/chart and text form and enables provide insights about how the ages of respondents influence their attitudes and emotions.

\subsection{The Distribution of the Respondents by Age}

Table 1: Respondents by Age

\begin{tabular}{cc}
\hline Age & Frequency \\
\hline $\mathbf{1 8 - 2 0}$ & 15 \\
$\mathbf{2 5}-\mathbf{3 5}$ & 21 \\
$\mathbf{3 5 - 4 5}$ & 20 \\
$\mathbf{4 5 - 5 5}$ and more & 2 \\
Total & 58 out of 60 respondents' \\
\hline
\end{tabular}

(Source: Results from Interview Questionnaires (2016). See Appendix)

Table 1 illustrates a greater number of women and girls in the interview were between 25 years to 45 years as the majority of women interviewed were in their early and late thirties, their answers turned to be more significant and specific as women around those ages were more affected and susceptible to start a family and have an occupation. Those within age 45-55 gave detailed answers due to their experience, while those within 18-20 gave partial answers due to their inexperience in life. 


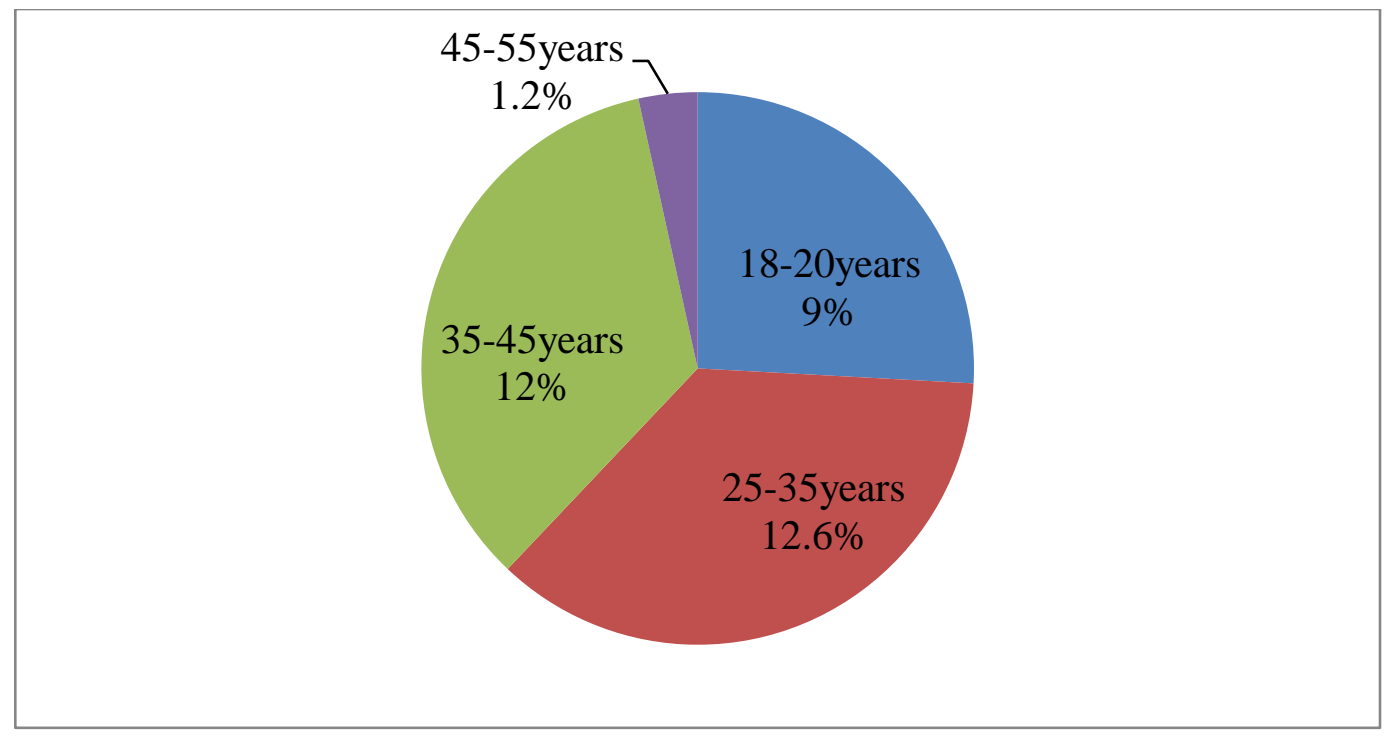

Figure 1:

Table 2: The Educational levels of Respondents

\begin{tabular}{|c|c|}
\hline Educational level & Respondents \\
\hline No education & 26 \\
\hline Basic education & 15 \\
\hline Secondary education & 10 \\
\hline Total & 51out of 60 resp. \\
\hline
\end{tabular}

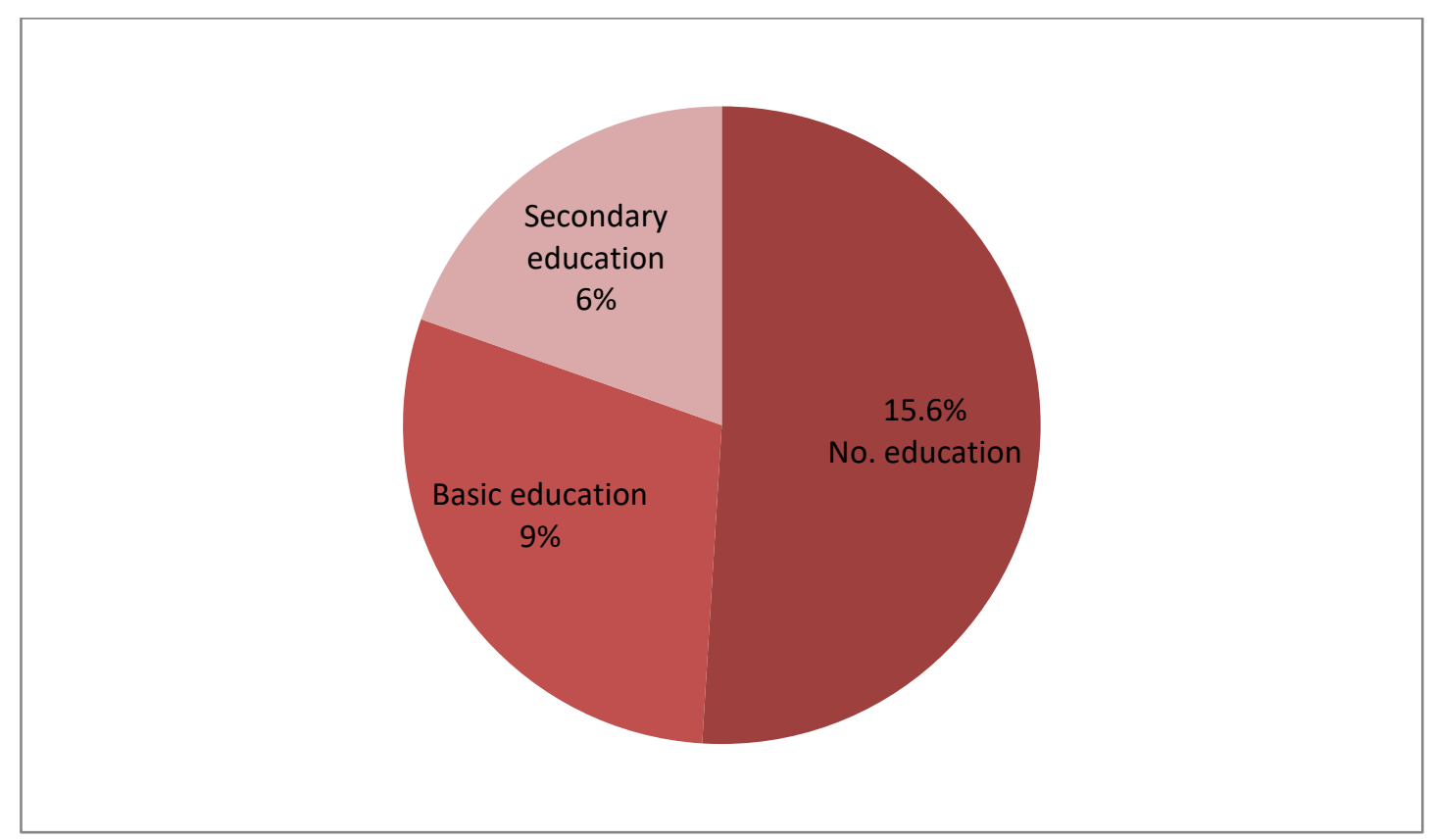

Figure 2:

(Source: Results from Interview Questionnaires (2016). See Appendix) 
The study looked at the respondents' educational backgrounds. The highest group showed that $15.6 \%$ had no education at all, while $9 \%$ had attained basic education, the percentage of those who had had secondary education stood at $6 \%$. From the results of the chart, the educational levels of the women were lower, and they were more likely to be less educated at the secondary level.

Table 3: Respondents' Marital Status

\begin{tabular}{|c|c|}
\hline Status & Interviewee \\
\hline Single & 20 \\
\hline Married & 13 \\
\hline Divorced & 10 \\
\hline Widowed & 17 \\
\hline Total & 60 \\
\hline
\end{tabular}

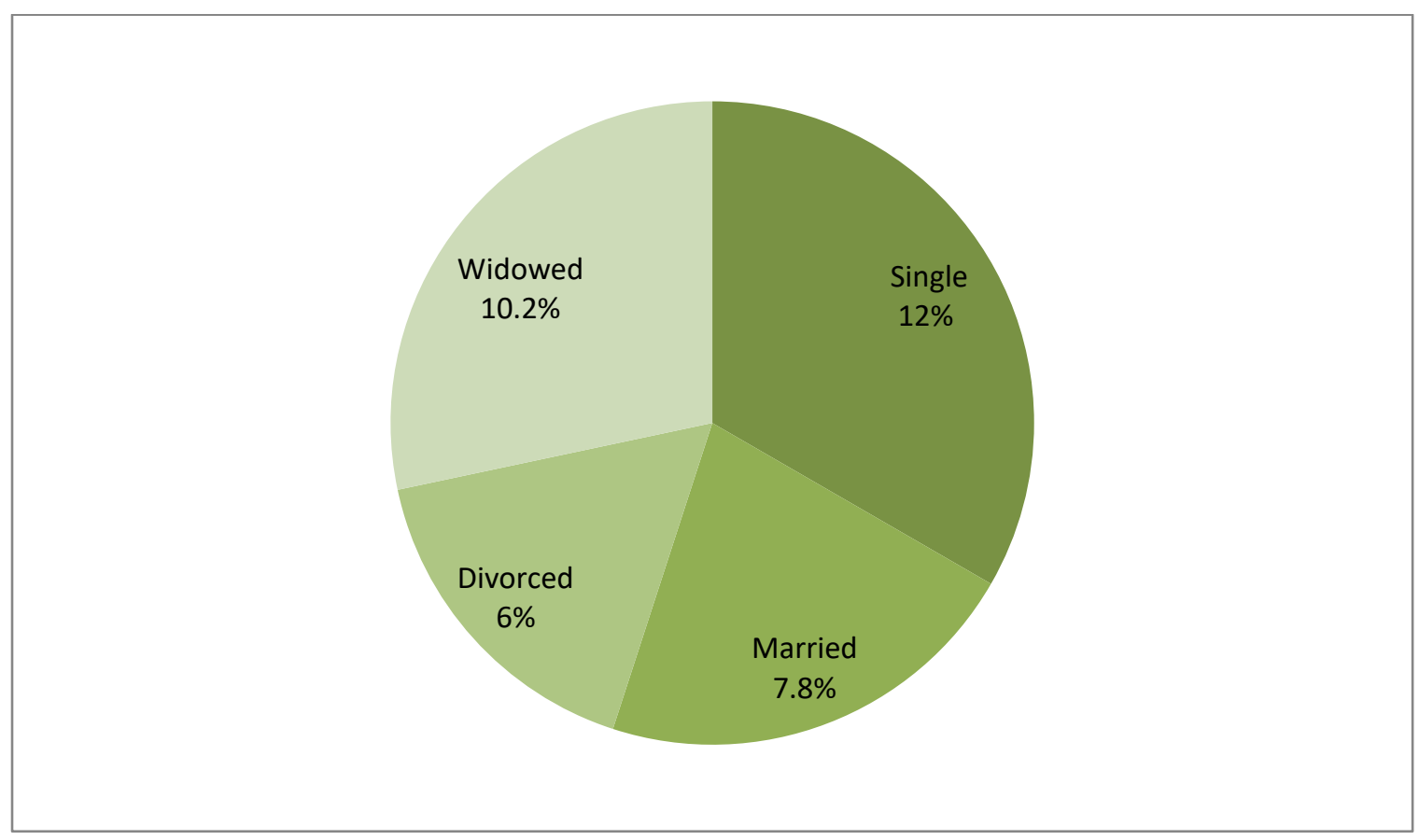

Figure 3:

(Source: Results from interview questionnaires (2016). See Appendix)

From this chart, the DRC has more single and widowed women than divorced and married which shows an indication of emotional instability which cannot favour development. Single women unlike married, divorced or widowed are more likely to depend on their families for support and assistance when facing certain problems that cannot favour their emotional stability. 
Table 4: Religion of the Respondents

\begin{tabular}{|c|c|}
\hline Religion & Respondents \\
\hline Christianity & 25 \\
\hline Islam & 3 \\
\hline Traditionalists & 0 \\
\hline Others & 39 \\
\hline
\end{tabular}

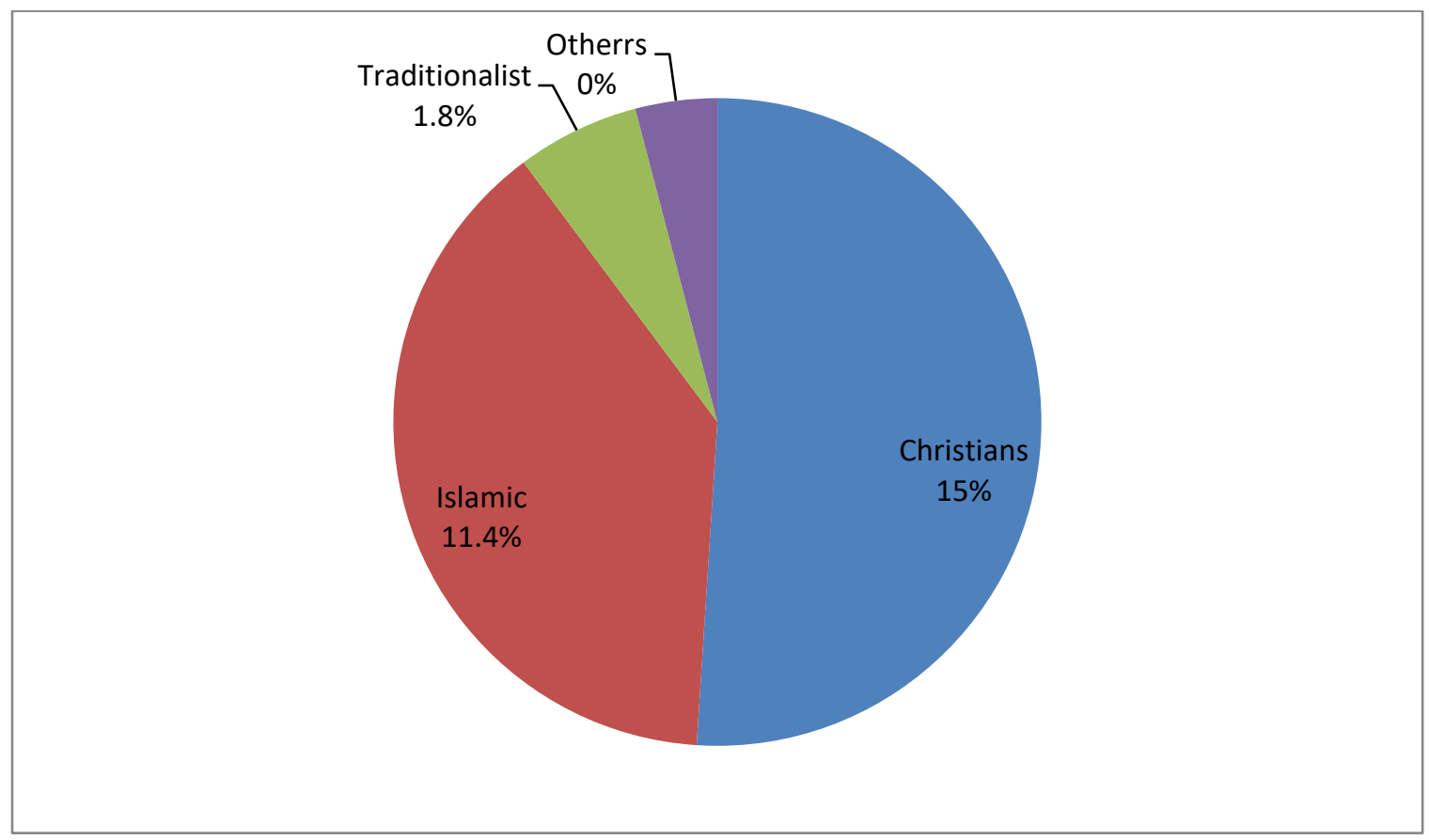

Figure 4:

(Source: From the Interview Questionnaire (2016). See Appendix)

The research conducted on their religious background showed that Christianity was the dominating religion among the participants and most of the answers were based on that fact. The relevance of religion in this study was related to the fact that most of the time people's attitudes and reasoning are a product of the religion they practice. So, the religious background helped the researcher to understand the assertion of the respondent's perception of rape.

\subsection{Occupation of the Respondents}

The economic activities assumed by the women were categorized into agriculture/farming, trading in any commodity and other services (dressmaking, teaching, nursing, etc.) 
Table 5: Economic Activities of the Respondents

\begin{tabular}{|c|c|}
\hline Economic Activities & Frequency \\
\hline Trading & 15 \\
\hline Farming & 25 \\
\hline Other services & 6 \\
\hline Total & 46 \\
\hline
\end{tabular}

(Source: From Interview Questionnaires (2016). See Appendix)

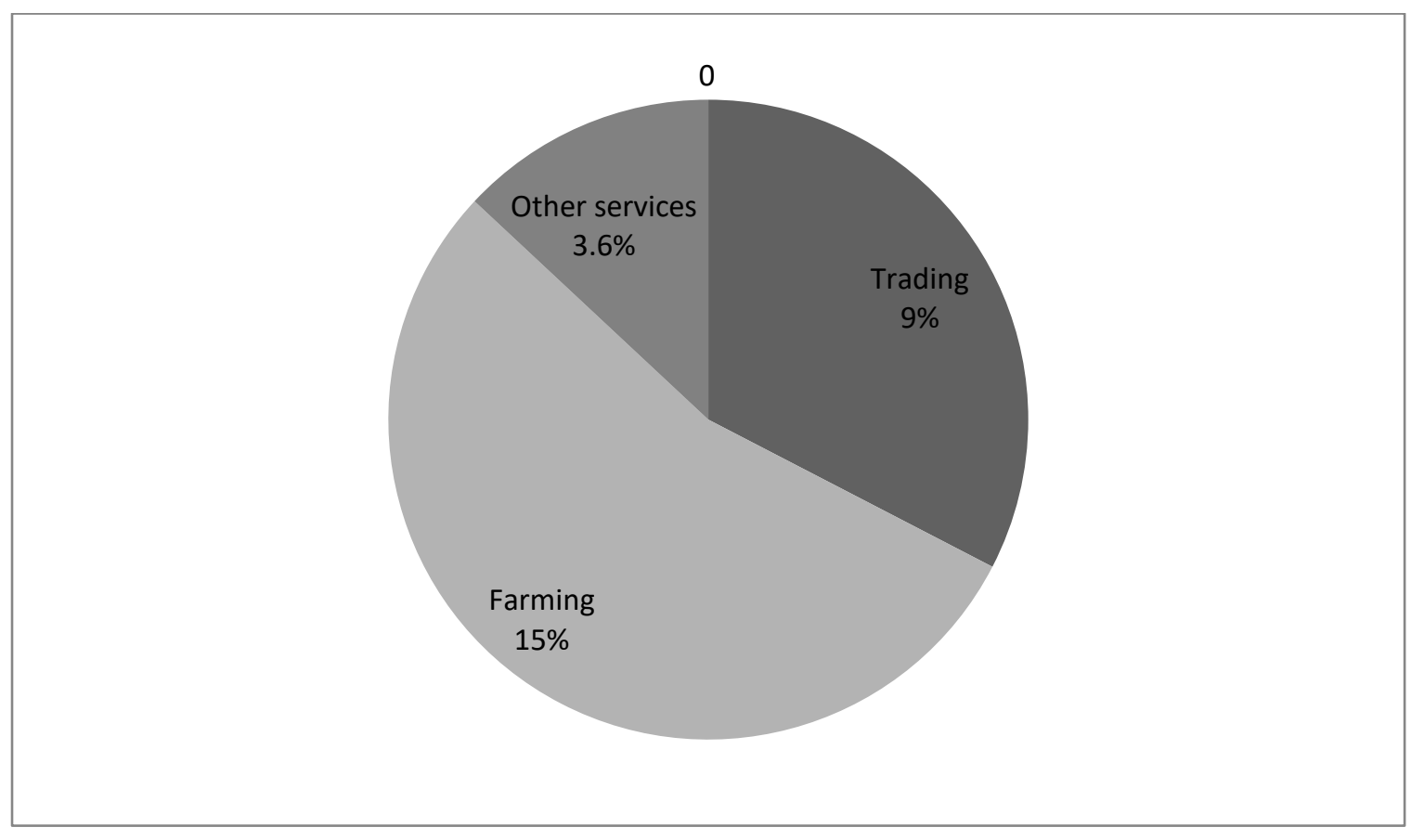

Figure 5:

The results showed that the majority of women $15 \%$ of the respondents were engaged in farming activities as they were able to earn some income to afford some basic needs, so were those in trading, contrary to the minority $3.6 \%$ of the women who found themselves in other works depended heavily on their peasant farming and petty trading mothers. In summary, this section provided an overview of the number of women interviewed in their economic activities.

\section{Data Analysis and Discussion of the Findings}

The study was analyzed and presented in three parts: which were the causes, effects and solutions. The data collected was carefully edited and analyzed based on their responses, focused on the findings of the study of the research objective which aimed at assessing the condition of women during and after the war in the DRC. As illustrated in table one, the study examined the psychological, physical, emotional and economic aspects of rape on women and girls of Goma of the DRC. 


\subsection{Assessment of Effects of Rape and Sexual abuse on the DRC Women and Girls in Goma}

This section examined the emotional effects of sexual abuse and rape as a result of the two wars, on women and girls, as described by the respondents for this study. The goal was to discover, to what extent the women and girls were affected emotionally and underlying factors. Based on the research findings, the emotional effects included; psychological and physical scars both on their minds and bodies, contraction of diseases, restriction of movement and imposition of curfews.

\subsection{Psychological and the Physical Effect of Rape on Women and Girls}

For items 27-39 of the structured interview questions (the appendix) which dealt with the emotional aspect of the victims, all the respondents (100\%) confirmed that the rape event during the wars has left a great psychological effect on them and this has affected their well-being as well as their perception about men, especially the young girls. It is therefore clear from the views of the respondents that sexual violence in general breeds some great negative implications on victims and their physical environment. The majority of respondents (42\%) also experienced some huge losses such as the destruction of their homes rendering them homeless, the destruction of schools, their businesses and farmlands as a result of the wars. However, (42\%) of the respondents were victims of rape particularly affected sexually whiles $(10 \%)$ of the respondents were still dealing with their psychological issues due to rape. Their responses indicated that the wars did not only affect them physically but also left psychological marks on the women and girls of Goma and as for death they could not recount. The findings are summarized in table 6 .

Table 6: Psychological and Physical Effects

\begin{tabular}{|c|c|c|}
\hline Variables & Frequency & Percentage \\
\hline Physical destruction & 25 & $42 \%$ \\
\hline Victims of rape & 25 & $42 \%$ \\
\hline Psychological effects & 10 & $16 \%$ \\
\hline Total & 60 & $100 \%$ \\
\hline
\end{tabular}

(Source: Results from Interview Questionnaires (2016). See Appendix)

\subsection{Assessment of the Social Aspect of the effect of Rape on Women and Girls}

This section discussed the social aspect of rape in the life of women and girls of the DRC.

Table 7: The Social Aspect of the Effect of Rape on Women and Girls

\begin{tabular}{|c|c|c|}
\hline Variables & Frequency & Percentage \\
\hline Women \& Girls in camps & 25 & $41 \%$ \\
\hline Victims with diseases & 21 & $35 \%$ \\
\hline
\end{tabular}




\begin{tabular}{|c|c|c|}
\hline Fake rape & 5 & $8.3 \%$ \\
\hline
\end{tabular}

(Source: Results from Interview Questionnaires (2016). See Appendix)

Based on the findings, the two wars extremely transformed lives in the North Kivu of the DRC as it generated casualties, the lives of women and girls were altered and restricted as well. Their formal normal way of living changed to a devastating one which affected their social lives as well as rejection from families.

Item 40-49 of the structured interview questions (the appendix) which dealt with the social aspect of rape in the lives of women and girls confirmed (41\%) of the respondents expressed their views of how their family members and friends rejected them, some by their husbands, they could no longer participate in certain social functions with ease as before which ended them in NGOs camps, (35\%) contracted some incurable diseases such as HIV/AIDS and other diseases as a result of rape.

Amidst all the enormity experienced by both women and girls of the North Kivu, the majority of them remained heartbroken and dissatisfied because of rape. Again, (8.3\%) of the respondent confirmed that in as much as rape cases have gone up, a number of them (women and girls) also fake sexual abuse. This was to get free medical attention provided by some NGOs in the name of assisting them to get health relief. This led the study in answering research questions 1 and 3. Based on this fact, the study deduced from the responses of the respondents that some NGOs have made rape a money-making event, making it appeal to the eyes of the world which have contributed to the increase of rape cases in the DRC.

This section analyses how war and sexual violence has affected the economic aspect of women. Economic activities were no more booming as before due to the issues of political unrest and sexual violence which affected the general market because most victims contracted diseases such as syphilis, HIV/AIDs, hepatitis, etc. with no medical care so they easily lose their lives thereby affecting their businesses.

Table 8: The Effect of Sexual Violence on Economic Activities

\begin{tabular}{|c|c|c|}
\hline Variables & Frequency & percentage \\
\hline Farmers & 25 & $41 \%$ \\
\hline Food Vendors & 15 & $25 \%$ \\
\hline Traders & 12 & $20 \%$ \\
\hline Hairdressing/dressmaking & 8 & $13.3 \%$ \\
\hline Total & 60 & $100 \%$ \\
\hline
\end{tabular}

(Source: From Interview Questionnaires (2016). See the Appendix) 
From this field result, the majority of $41 \%$ were farmers. According to them, they could no longer go to their farms to work as they used to in the past due to fear of being raped hence, they were no more in the position to assist their families financially. The $(25 \%)$ of food vendors could no longer cook to sell due to ill health, $(20 \%)$ of traders could not go to trade anymore because of fear and stigmatization from families, friends, and the society at large. Among the respondents interviewed, $(13.3 \%)$ who were hairdressers/dressmakers expressed their uncertainty concerning the future of their work as inflows were not as high as before. Consequently, businesses went down as a result of the economic crunch; they could not afford the cost of their health let alone afford for their adornments. Due to this, they resorted to depending on foreign donors who travel to and fro to get what they want which eventually ends them in prostitution or being raped as usual.

Generally, the effect of rape on women and girls is viewed as traumatic and disastrous due to the huge damages it causes. For instance, the (41\%) farmers of this study believed in the wars as the causal factor of their current pain.

\section{Conclusion}

The brutalities of the 1998 war in the Eastern part of The DRC lasted for ten years but were somehow volatile due to tribal parting, foreign pressure and a battle over the natural resources of the country. What this article deduced from the issue of the DRC being the capital of rape, answers research question number 3: to find out if rape cases in the DRC were a way of making money by the influence of external bodies or the belief of the people? This is not a belief but, in a way, moneymaking by both some supposed NGOs and natives. Nonetheless, per the findings, it remains questionable as the DRC is labelled the rape capital of the world. What yardstick does the world use to measure the capital of rape? Rape cases in that region was on the increase perhaps due to fake rape by some indigenes and some international organizations whose sole aim is to exploit the natural resource of that part of the country, hence dinner for some international NGOs and rebels from neighbouring countries.

Are neighbouring countries and international organizations still trooping in to exploit the natural resources of the country? And last, but not least is the DRC truly the rape capital of the world, is this not a myth or probably a stereotype? And what conscious effort has the African Union and the United Nations made to resolve this menace once and for all since it is the capital of rape in the world?

\section{Recommendation}

- In the case of DRC, there should be the establishment of a new search of violations, in that the office of the military prosecutor will look into possible atrocities carried out in the Eastern 
part of the DRC and its environs that have not been formally indicted, according to the laws of the jury.

- The national investigations' prosecutions must be quality and strengthened, to draft and highlight objectives and priority needs; which includes the government's contribution to beef up accountability.

- Again, it will be prudent to integrate gender into the United Nations peacekeeping mission in the DRC (MONUSCO) and other global stakeholders to put on an autonomous state security plan for the abused and eyewitnesses of heinous global violence.

- This is a call for international bodies, including Human Rights Watch and the presidency of the African Union and the European Union at large since it is the capital of rape it is a world issuea

\section{REFERENCES}

Amnesty International, Rape as a Tool of War: A Fact Sheet, 2007.

https://www.refworld.org/docid/46558ed820.html

Baaz, M.E., \& Stern, M. (2009). Why Do Soldiers Rape? Masculinity, Violence, and Sexuality in the Armed Forces in the DRC, International Studies Quarterly 53(2), 495-518. https://doi.org/10.1111/j.1468-2478.2009.00543.x

Brown, C. (2011). Rape as a weapon of war; in the Democratic Republic of the Congo.

Cammaert, P. (2008). A Peacekeeping Commander's Perspective: From Headquarters and the Field. The RUSI Journal 153 (3), 68-71, 2008. https://doi.org/10.1080/03071840802249612

Duncan, N. (Ed.). (2004). Self, community and psychology. Juta and Company Ltd.

Easteal, P. (2011). Sexual Assault Law in Australia: Contextual Challenges and Changes. International approaches to rape, 13. https://doi.org/10.1332/policypress/9781847426208.003.0002 https://doi.org/10.2307/j.ctt9qgkd6.5

Gentleman, J. (2007). Rape Epidemic Raises Trauma of Congo War. New York Times. International Rescue Committee, (2007). Measuring Mortality in the Democratic Republic of Congo. Katanga and Ngudjolo Chui Cases Coalition for the International Criminal Court. Retrieved from www.iccnow.org/?.drctim... on Aug. 3, 2015.

Green, R. (1987). The" sissy boy syndrome" and the development of homosexuality. Yale University Press. https://doi.org/10.2307/j.ctt1ww3v4c 
Harris, S., Jefferson-James, L., Ligon, A. D., Davis, C., Adelabu, D. H., Wynn, M. F., ... \& Nelson, T. A. (2015). Real Sister: Stereotypes, Respectability, and Black Women in Reality TV. 31. Rutgers University Press.

Lundberg-Love, P. K. (1999). The resilience of the human psyche: Recognition and treatment of the adult survivor of incest. The Psychology of Sexual Victimization: A Handbook, 1.

Pratt, M. \& Werchick, L.J.D. (2004). Sexual Terrorism: Rape as a Weapon of War in The Eastern Democratic Republic of Congo. USAID/DCHA ASSESSMENT REPORT Sexual Terrorism: Rape as a Weapon of War in Eastern. An assessment of programmatic responses to sexual violence in North Kivu, South Kivu, Maniema, and Orientale Provinces January 9$16,2004$.

https://us.search.yahoo.com/search?fr=yhsinvalid\&p=USAID\%2FDCHA+Assessment+Rep ort\%2C+2004 Retrieved June 2016.

Penn, M. L., Nardos, R., Hatcher, W. S., \& Radpour, M. K. (2003). Overcoming violence against women and girls: the international campaign to eradicate a worldwide problem. Rowman \& Littlefield.

Simon, R., Rathborne, J. M., Shah, R. Y., Jackson, J. M., \& Chambers, E. T. (2006). The characterization and galactic distribution of infrared dark clouds. The Astrophysical Journal, 653(2), 1325. https://doi.org/10.1086/508915

Tear fund HIV \& SV Unit, (2014). Men, Faith and Masculinities: DRC, a baseline assessment on the relation attitudes, relations and practices of men concerning gender and sexual-based violence in the DRC 2014. https://learn.tearfund.org//media/learn/resources/reports/burundireport-final.pdf. Retrieved June 2016

The International Peace Research Institute, 2001. https://www.ipinst.org/category/publications/page/2

UNIFEM, (2010). Facts and Figures on Violence against Women, Crimes against Women in Situations of Armed Conflict.

Wolf, S., Aber, J. L., Torrente, C., Rasheed, D., \& McCoy, M. (2014). Cluster-Randomized Trial of a Large-Scale Education Initiative in the Democratic Republic of Congo: Pilot Year Impacts on Teacher Development. Society for Research on Educational Effectiveness.

Wax, E. (2003). A generation orphaned by AIDS. The Washington Post, August, 13, A18. World Health Organization. (2008). Eliminating female genital mutilation: an interagency statement-OHCHR, UNAIDS, UNDP, UNECA, UNESCO, UNFPA, UNHCR, UNICEF, UNIFEM, WHO. World Health Organization. UNIFEM 


\section{APPENDIX INTERVIEW QUESTIONAIRE (2016)}

\section{Note to all Respondents}

I would like to first and foremost thank you personally for accepting to answer this interview. I am grateful for your time and readiness. This interview intends to find out how the Eastern part of the DRC became the rape capital of the world, the effects of rape on women and girls as a result of the wars and how the war has affected the lives of women in the Eastern part of DRC. Be rest assured the details of this interview will be kept confidential and private so please feel at ease to express your opinions and suggestions.

Thank you so much for your cooperation.

General information about Congolese women and girls in the Eastern part of DRC.

Please tick Yes $\sqrt{ }$ and No Age

1. Community

2. Nationality

3. Religion / Faith: Christianity [ ] Islam [ ] Traditional [ ]

4. Marital Status: married [ ] single[ ] widowed [ ] divorced [ ] separated[ ]

5. Married for how many years?

6. Number of dependents: own children [ ] other [ ] total [ ]

7. Occupation

8. Educational level: nil [ ] primary [ ] JSS / middle [ ] SSS / Technical [ ] Tertiary [ ]

\section{Structured Interview Questions.}

9. Do you know that the Eastern part of DRC is the capital of rape in the world?

Yes [ ] No [ ]

10. Why is it the capital of rape? Give three reasons.

11. What is the cause of rape in the Eastern part of the DRC?

12. Are you happy that it is the capital of rape? Yes [ ] No [ ]

13. Give three reasons why you are not happy if not.

14. Are people still discussing the effects of rape on their lives? Yes [ ] No [ ]

15. Do you believe that with time Congolese will forget the painful event of the two wars in DRC? Yes [ ] No [ ]

16. Are there any measures put in place to prevent future occurrences of rape? 
Yes [ ] No [ ]

17. Give three of the measures if yes.

18. Are soldiers and rebels still fighting in the Eastern part of the DRC? Yes [ ] No [ ].

19. What is the root cause of the war?

20. What makes soldiers rape during the war?

21. Is rape in the DRC a way of making money or a belief?
(a) A way of making money [ ]
(b) A belief [ ]

22. What is your general view of rape? Neutral [ ] Normal [ ] Bad [ ] Good [ ]

\section{Assessment of Emotional Effects of Rape Sexual Violence in the Eastern part of DRC.}

23. Were you a victim of sexual violence? Yes [ ] No [ ]

24. How were you handled by the perpetrators?

25. Has the rape incident left any psychological and physical scars on you? Yes [ ] No [ ]

26. Did you contract any form of the disease as a result of the rape? Yes [ ] No [ ]

27. Which disease have you been infected with, if yes?

28. Did you partake in any form of violence? Yes [ ] No [ ]

29. If yes, give three reasons behind your involvement.

30. Some soldiers say they did not know rape was and is a crime. True [ ] False [ ]

31. Does the occurrence of violence restrict your movement? Yes [ ] No [ ]

32. If yes, how has it affected your movement?

33. Are women being raped, even now? Yes [ ] No [ ]

34. Who raped them, their husbands or rebels? Their husbands [ ] Rebels [ ]

35. Why will husbands rape their wives?

\section{Assessment of the Social Aspect of Rape on Women and Girls in the Eastern part of DRC.}

36. How were raped women and girls treated in society?

37. How were they treated by their family members?

38. Were they excommunicated by their families and society because they were raped? Yes [ ] No [ ]

39. Where were the victims sent to when they were excommunicated?

40. Who takes care of them or how do they survive when they are excommunicated?

41. Do the rape victims get any external aid/help? Yes [ ] No [ ]

42. Give three examples of these external bodies. 
43. What kind of aid do these external bodies give?

44. Do you know that some women and girls fake rape to get free health care? Yes [ ] No [ ]

45. If yes, how is it done?

\section{Assessment of the economic aspect of war and sexual violence on women and girls}

46. Has the issue of rape affected the general market? Yes [ ] No [ ]

47. If yes, how?

48. Generally, is there an outbreak of disease as a result of the war? Yes [ ] No [ ]

\section{Unstructured general interview questions}

49. If yes, mention three of these outbreaks of these diseases.

50. How has the rape issue affected your normal life/marriage?

51. What do you think can be done to lift the stigma or brand name off DRC: the capital of rape in the world?

52. Do you think the lives of rape victims can go back to normalcy? Yes [ ] No [ ] 53 If yes, how?

Thank you very much for your attention.

\section{The Questionnaire was based on these Research Questions:}

1. Why is the Eastern DRC the capital of rape in the world?

2. Why are women raped now and then?

3. Is the issue of rape in the DRC a way of making money or a belief?

4. Are there governmental interventions to curb the rape cases that have already been reported? 